\title{
Repercussions of impeding shipping in the Malacca and Singapore Straits
}

\author{
Peter J. Rimmer and Paul T.W. Lee*
}

\begin{abstract}
As the Malacca and Singapore Straits are part of the shortest route between Europe and Asia any impedance to shipping has serious commercial and strategic repercussions. What would be the consequences to tankers and container shipping if access was restricted or prevented? This issue is addressed by examining the costs of using alternative tanker routes to the Straits and the flow-on consequences of removing a mega-hub port from the container-shipping network. The analysis highlights differences between tanker shipping, where the ship itself is the prime unit of interest, and container shipping, where the door-to-door network is of paramount importance.
\end{abstract}

Keywords: container shipping; hub-and-spoke system; tankers; mega-ports; supply chain management.

\section{Introduction}

In March 2006 the United States Congressional Budget Office (CBO) released Report on the economic costs of disruptions in container shipments at the ports of Los Angeles and Long Beach due to both an unexpected one week halt triggering a one-month backlog, and an unexpected three year halt and precautionary one week stoppage at all other US ports (CBO, 2006: 11-22). More briefly, the Report also considered the possibility of an unexpected forced shutdown of Hong Kong, the largest single source of container shipments to the US, worth over US\$43 billion in 2004 (CBO,

Submission Date: 25/9/2006 Acceptance Date: 30/5/2007

"Peter J. Rimmer is Hanjin Shipping Chair Professor of Global Logistics, Asia Pacific School of Logistics, Inha University, Incheon, Korea and Visiting Fellow, Division of Pacific and Asian History, The Australian National University, Canberra, ACT, Australia 0200; and Paul T.W. Lee is a professor, Department of Logistics and Shipping Management, Kainan University, Taiwan, email: paultwlee@mail.knu.edu.tw 
2006: 25-27). The Report suggests that any closure would be likely to force other regional ports to undertake the consolidation task or, additionally, the transhipment process being foregone and a switch made to smaller ships. As thirteen of the top-20 ports are located in East Asia the Report suggests that these ports would have significant opportunities to pick up any slack from Hong Kong.

The reference to Hong Kong prompts us to take a wider view of the maritime scene in East Asia by considering the effects of disruptions not only to container shipping but also bulk shipping because, without energy and raw material supplies from the Middle East and Australia, the shipments of finished goods generated by China and neighbouring Japan and Korea for the US market would simply not occur. We undertake this task by focusing on the Straits of Malacca and Singapore, which offer the shortest and quickest route between the Middle East Gulf and East Asia (Fig. 1)

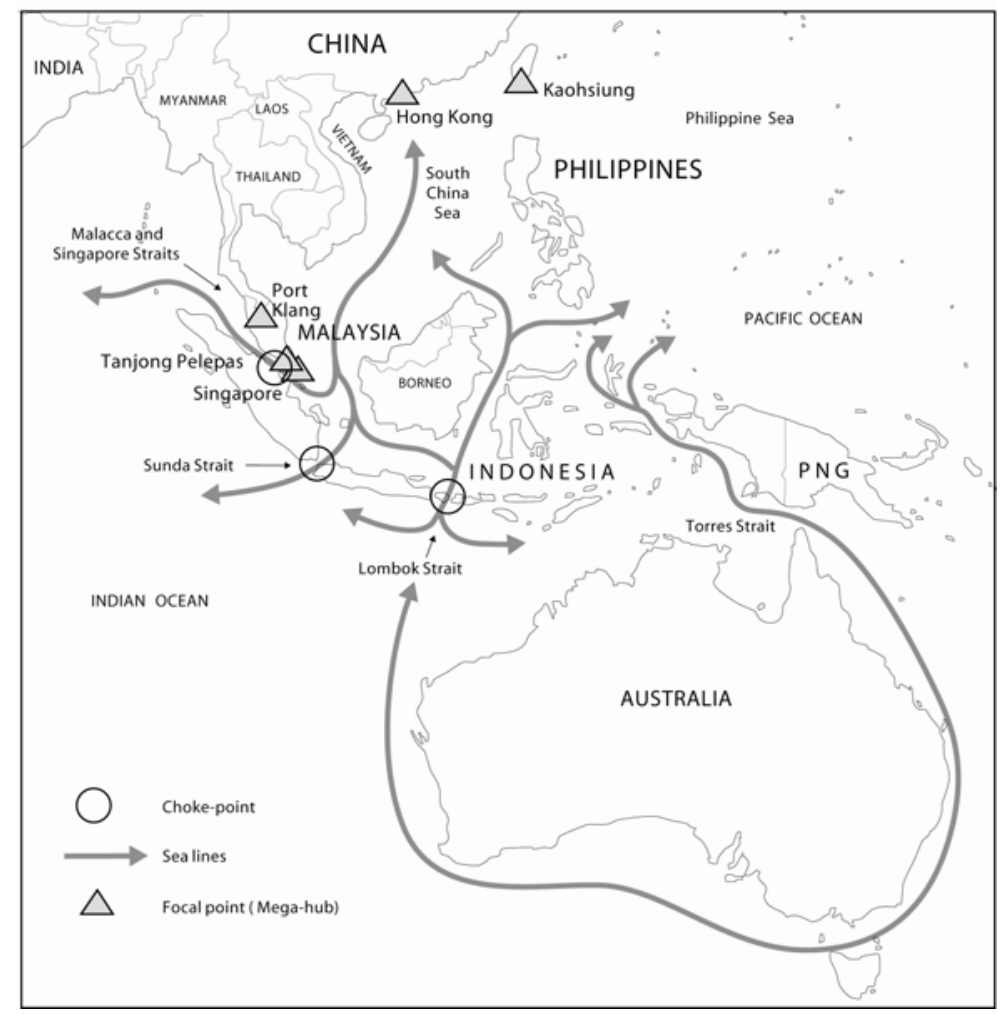

Source: Based on Akimoto (2001a)

Fig 1. Choke-points, sea lines of communication and hub ports

Two critical issues are raised about the Straits of Malacca and Singapore: (a) how would the bulk shipping react to any impedance to vessel movements; and (b) would container shipping react 
any differently? These issues are addressed by initially drawing attention to the crucial importance of the Straits of Malacca and Singapore in world shipping through a brief review of the literature and a search of the Lloyd's List (2006) archives to determine if there are plausible reasons for the impedance of shipping. Then an examination is made of the distances, time and costs involved for tanker shipping of any diversion from the Straits of Malacca and Singapore. A similar analysis is conducted for container shipping but there is a major difference because, unlike bulk shipping where the ship itself is the major unit of analysis, we are dealing with a door-to-door network and the removal of a core hub, such as Singapore, makes it difficult to assess the economic costs of port closure and whether other regional ports are in a position to compensate for the disruption in the supply chain. Consequently, the study is augmented by information drawn from a series of case studies of shipping companies operating, singly or in tandem, tankers and container ships.

\subsection{Impedance}

Traffic in the Malacca and Singapore Straits has been expanding. Trends between 2000 and 2004 suggest that movements in excess of 65,000 vessels per annum are now expected (Table 1). Not only do these vessels carry one-third of global trade but also four-fifths of East Asia's imports of crude oil, as the Straits offer the best option for ships plying between the Indian Ocean and the Pacific Ocean. The key user states of Japan, Korea and, more recently China, are concerned about keeping this vital artery open as it is not only the shortest route but the most secure by virtue of its serviceable navigational aids.

Table 1

Shipping traffic in the Straits of Malacca and Singapore, 2000-2004

\begin{tabular}{|c|c|c|c|c|c|c|c|c|c|c|}
\hline \multirow{2}{*}{ Vessel } & \multicolumn{2}{|c|}{2000} & \multicolumn{2}{|c|}{2001} & \multicolumn{2}{|c|}{2002} & \multicolumn{2}{|c|}{2003} & \multicolumn{2}{|c|}{2004} \\
\hline & no. & $\%$ & no. & $\%$ & no. & $\%$ & no. & $\%$ & no & $\%$ \\
\hline $\begin{array}{l}\text { VLCC/Deep } \\
\text { Draft }\end{array}$ & 3,163 & 6 & 3,303 & 6 & 3,301 & 6 & 3,487 & 6 & 3,477 & 6 \\
\hline Tanker & 13,343 & 24 & 14,276 & 24 & 14,591 & 24 & 15,667 & 25 & 16,403 & 26 \\
\hline LNG/LPG & 2,962 & 5 & 3,086 & 5 & 3,141 & 5 & 3,277 & 5 & 3,343 & 5 \\
\hline $\begin{array}{l}\text { General } \\
\text { Cargo }\end{array}$ & 6,603 & 12 & 6,476 & 11 & 6,065 & 10 & 6,193 & 10 & 6,624 & 10 \\
\hline Container & 18,283 & 33 & 20,101 & 35 & 20,091 & 33 & 19,575 & 31 & 20,187 & 32 \\
\hline Bulk Carrier & 4,708 & 8 & 5,370 & 9 & 5,754 & 10 & 6,256 & 10 & 6,531 & 10 \\
\hline $\begin{array}{l}\text { Ro/Ro } \\
\text { Car Carrier }\end{array}$ & 1,761 & 3 & 1,764 & 3 & 1,980 & 3 & 2,182 & 4 & 2,440 & 4 \\
\hline Passenger & 3,301 & 6 & 3,151 & 5 & 3,490 & 6 & 3,033 & 5 & 2,838 & 4 \\
\hline Other & 1,833 & 3 & 1,787 & 3 & 1,621 & 3 & 2,664 & 4 & 1,793 & 3 \\
\hline Total & 55,593 & 100 & 59,314 & 101 & 60,034 & 100 & 62,334 & 100 & 63,636 & 100 \\
\hline
\end{tabular}

Source: Abd. Rahim bin Hussin (2005) 
An early attempt to estimate the economic value of the Straits was made by Hisayoshi Morisugi, James Barney Marsh and Nobuharu Miyatake (1992). Their findings were intended to assist in the assessment of:

1. the cost-effectiveness of a 'user pays system' for the sea lane proposed by the littoral states of Indonesia, Malaysia and Singapore;

2. a possible canal across the Kra Isthmus proposed by Thailand; and

3. a maximum limit to investments by user states, notably through Japan's philanthropic Nippon Foundation, in the Strait's navigation aids and other projects.

Morisugi and others defined the economic value as the present value of annual costs savings due to the availability of the Straits. These annual costs savings were calculated as the difference in annual transport costs between the Straits and the second best routes - the Lombok Strait for tankers and the shallower and congested Sunda Strait for other vessels — on the assumption that all ships passing through the Straits would choose the best route in terms of transport cost. Calculations were made for 250,000 dwt tankers and container ships with a capacity of 500 TEU. While this method of deriving the present value of the annual cost savings from shipping still has some utility, the original findings derived from a flow analysis have been overtaken by subsequent events, not least the increase in size of container ships.

These events are revealed in an analysis of 500 entries derived from interrogating Lloyd's List archives between 1990 and June 2006 (Table 2). During the 1990s navigational safety and pollution issues, linked to collisions between ships and oil spills in the congested Straits and the need for a traffic system to accommodate larger ships, overshadowed security concerns involving piracy (Rimmer, 2003; Djalal, 2004). After 2000 there was a marked change in the character of entries. The need to combat piracy and its possible links to terrorism following the events of 9/11 led to regional security becoming the dominant subject of interest as both the International Maritime Organization (IMO) and the US Navy became more involved in the region (Desker, 2005; Raymond, 2005a,b; Wilkins, 2004). Meanwhile, the safe navigation of larger vessels, if not the pollution issue, remained a continuing matter of concern in the headlines. In 2005 the decision of the Joint War Committee of Lloyd's Market Association in London to put the Malacca Strait on its enhanced risk list and liable to an insurance surcharge has boosted the overall dominance of the security topic (Chen, 2006). Although the surcharge was removed on 7 August 2006, security remained of paramount interest. 
Table 2

References to Malacca strait in Lloyd's list headlines, 1990-2006

\begin{tabular}{l|c|c|c|c|c|c|c|c|c}
\hline \multirow{2}{*}{ Year } & \multicolumn{2}{|c|}{ Navigation } & \multicolumn{2}{c|}{ Pollution } & \multicolumn{2}{c|}{ Security } & \multicolumn{2}{c|}{ Other } & \multirow{2}{*}{ Total } \\
\cline { 2 - 9 } & no. & $\%$ & no. & $\%$ & no. & $\%$ & no. & $\%$ & \\
\hline \hline $1990-94$ & 36 & 30.5 & 18 & 15.3 & 24 & 20.3 & 40 & 33.9 & 118 \\
$1995-99$ & 15 & 23.8 & 11 & 17.4 & 17 & 27.0 & 20 & 31.8 & 63 \\
$2000-04$ & 20 & 10.5 & 1 & 0.5 & 144 & 75.8 & 25 & 13.2 & 190 \\
$2005-06$ & 13 & 10.1 & 2 & 1.6 & 107 & 82.9 & 7 & 5.4 & 129 \\
\hline Total & 84 & 16.8 & 32 & 6.4 & 292 & 58.4 & 92 & 18.4 & 500 \\
\hline
\end{tabular}

Note: Sorted on 'Malacca'.

Source: Derived from Lloyd's List (2006) Archives.

Piracy and armed robbery in the Malacca and Singapore Straits have persisted between 1990 and 2006 and are reflected in part in protection and indemnity (P\&I) premium ratings (IMB, 2006a,b; IMO, 2006a,b). Although Table 3 shows the number of actual and attempted piracy and armed robbery attacks had receded from their peak levels due, in part, to the intervention of the naval forces of the littoral states and the 2004 tsunami. The addition of the Malacca and Singapore Straits on the enhanced risk list by the Joint War Committee in 2005 stemmed from a more overt concern with threats of maritime terrorism. While risk assessors would rate the likelihood of piracy as 'almost certain' and maritime terrorism as 'possible', the potential economic disruption to trade from the former would be low whereas the impact of the latter would probably range, depending on the length of time of the of sea-lane closure, from significant to catastrophic (Brown, 2005).

Table 3

Locations of actual and attempted attacks, 1994-2005

\begin{tabular}{|c|c|c|c|c|c|c|c|c|c|c|c|c|}
\hline Location & 1994 & 1995 & 1996 & 1997 & 1998 & 1999 & 2000 & 2001 & 2002 & 2003 & 2004 & 2005 \\
\hline Malacca & 3 & 2 & 3 & 0 & 1 & 2 & 75 & 17 & 16 & 28 & 38 & 12 \\
\hline Singapore & 3 & 2 & 2 & 5 & 1 & 14 & 5 & 7 & 5 & 2 & 8 & 7 \\
\hline Sub-total & 6 & 4 & 5 & 5 & 2 & 16 & 80 & 24 & 21 & 30 & 46 & 19 \\
\hline Indones & 22 & 33 & 57 & 47 & 60 & 115 & 119 & 91 & 103 & 121 & 94 & 79 \\
\hline Other & 10 & 34 & 62 & 40 & 27 & 30 & 42 & 38 & 29 & 19 & 18 & 4 \\
\hline SE Asia & 44 & 75 & 129 & 97 & 91 & 177 & 321 & 177 & 174 & 200 & 204 & 121 \\
\hline $\begin{array}{l}\text { Rest } \\
\text { of world }\end{array}$ & 52 & 117 & 104 & 156 & 113 & 139 & 228 & 182 & 217 & 275 & 171 & 174 \\
\hline Total & 90 & 188 & 228 & 248 & 202 & 300 & 469 & 335 & 370 & 445 & 329 & 276 \\
\hline \%SE Asia & 42 & 38 & 54 & 37 & 44 & 54 & 51 & 46 & 41 & 38 & 48 & 37 \\
\hline
\end{tabular}

Source: Derived from IMB(2006a: 5). 
This prospect of maritime terrorism in the Malacca Straits has resulted in strategic and defence analysts considering a range of scenarios detailing how this could eventuate (Coulter, 2002; Bergin and Bateman, 2005). In particular, the sheer number of possibilities has prompted Catherine Zara Raymond (2006) to sift through these scenarios and declare most to be extremely unlikely and impractical. For instance, she deems unfeasible the potential sinking of a ship in the Straits of Malacca and Singapore in such a way as to block the sea-lane and create worldwide economic havoc. As the narrowest point at One Fathom Bank is still 0.6 nautical miles wide vessels would be able to navigate around the sunken ship (Fig. 2). While Raymond considers maritime attacks are likely to be rare due to the current lack of capability of would-be terrorists, the probability cannot be ignored altogether.
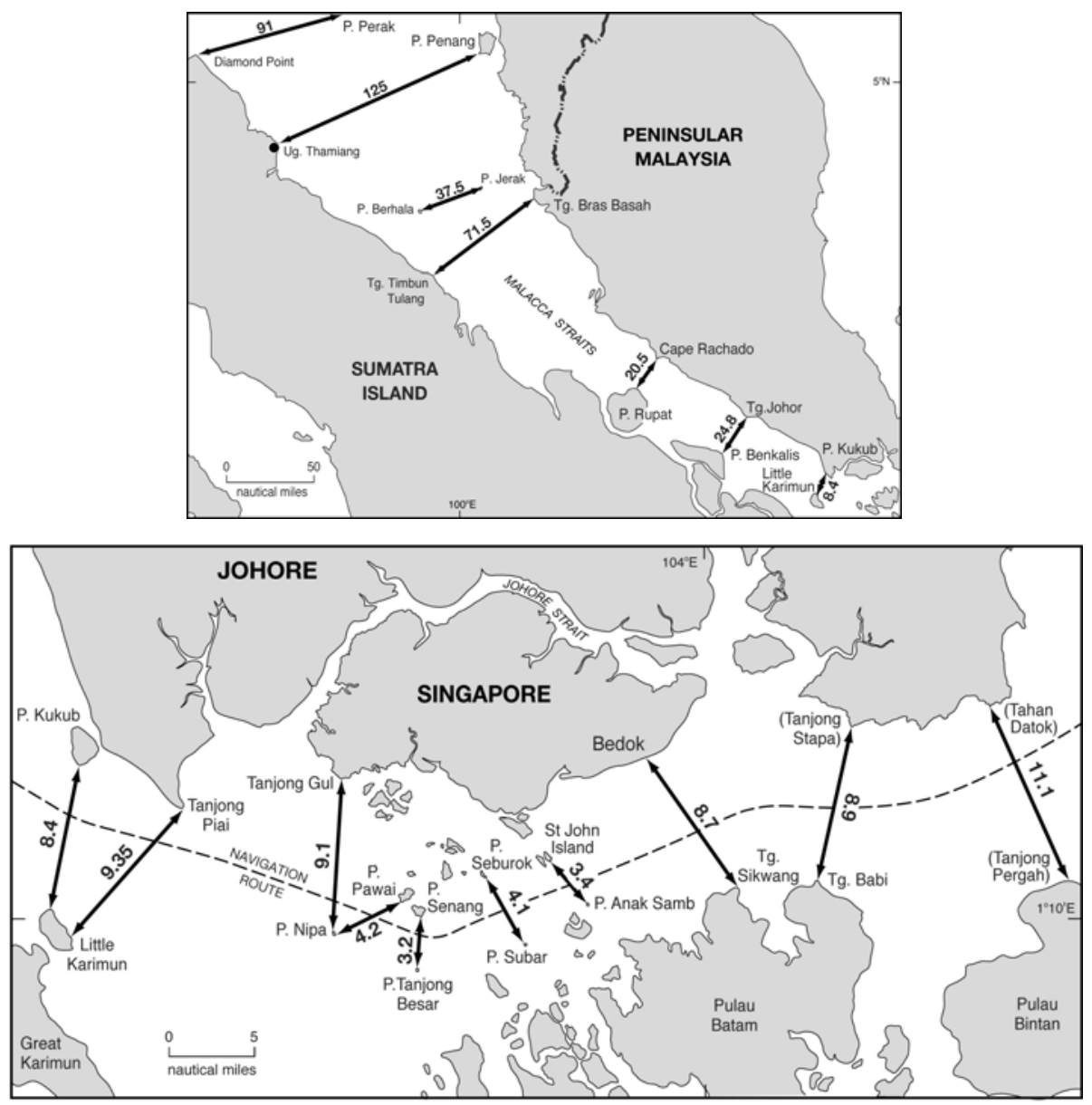

Note: The maps are based on British Admiralty charts. Source: Koh(1982)

Fig 2. The Straits of Malacca and Singapore: (a) the Malacca Strait; and (b) the Singapore Strait 
Indeed, Raymond proceeds to investigate three other scenarios: (a) the blocking of the Malacca Strait by mines; (b) the use of a tanker as a floating bomb to strike key ports; and (c) a missile launched at aircraft from a vessel. These scenarios are detailed in Table 4 because they feature the Straits of Malacca and Singapore and the hub port of Singapore, and highlight the need for anti-maritime terrorism exercises. The scenarios are also important because Raymond concludes that any comprehension of the terrorist threat stems not only from appreciating the motivations of the likely terrorists but understanding the nature of the maritime environment. Although Raymond makes reference to the possibility of severe delays to shipping, increased shipping costs and the impacts on world trade, no figures are offered. An earlier attempt to provide such figures by Kazumine Akimoto (2001a,b; 2002) based on Japanese experience was flawed by the absence of detailed methods of calculation. We have sought to remedy this deficiency, albeit from a Korean perspective.

Table 4

Maritime thrrorism in the straits of Malacca and Singapore: potential scenarios

\begin{tabular}{|c|c|c|}
\hline Action & Impact & Comment \\
\hline $\begin{array}{l}\text { 1.Straits of Malacca } \\
\text { blocked by mines }\end{array}$ & $\begin{array}{l}\text { Straits blocked to traffic due to actual } \\
\text { mining or threat to mine seaways. }\end{array}$ & $\begin{array}{l}\text { Vessels, especially those on international } \\
\text { voyages, would be rerouted via Sunda } \\
\text { Strait and Lombok Strait. }\end{array}$ \\
\hline $\begin{array}{l}\text { 2.Tanker as floating } \\
\text { bomb to strike ports }\end{array}$ & $\begin{array}{l}\text { The hijacking of a Liquid Nitrogen } \\
\text { Gas (LNG) tanker \& blowing it up in } \\
\text { Singapore harbor would devastate } \\
\text { Singapore; the Singapore Government } \\
\text { considers the impact on global trade } \\
\text { would be severe and incalculable. } \\
\text { Potential threat from ships carrying } \\
\text { high-risk cargoes intensified by the } \\
\text { high number of pirate attacks. }\end{array}$ & $\begin{array}{l}\text { The potential to cause damage will vary } \\
\text { with the differing capacity of each vessel } \\
\text { and its cargo, the means of triggering the } \\
\text { explosion, and the actual impact on the } \\
\text { port facility. Effects of an LNG tanker } \\
\text { explosion would be limited by its } \\
\text { location; an oil tanker would cause a } \\
\text { localized fire; and a chemical tanker } \\
\text { would have a toxicity risk. }\end{array}$ \\
\hline $\begin{array}{l}\text { 3.Surface-to-air(SAM) } \\
\text { Missile launched at } \\
\text { aircraft from vessel }\end{array}$ & $\begin{array}{l}\text { Impact on Singapore would be } \\
\text { massive, not only due to loss of life, } \\
\text { closure of the airport and immediate } \\
\text { effect on the Singaporean economy but } \\
\text { because there is no guarantee that a } \\
\text { similar attack would not be carried out } \\
\text { in future. }\end{array}$ & $\begin{array}{l}\text { Short of inspecting every ship little law } \\
\text { enforcement agencies can do to mitigate } \\
\text { the effect. }\end{array}$ \\
\hline
\end{tabular}

Source: Raymond (2006) 


\section{Tankers}

More than 23 meters of water depth are required for very large crude carriers (VLCC) when passing southward through the IMO-adopted Traffic Separation Scheme (TSS) of the Malacca and Singapore Straits covering 263 nautical miles (Fig. 3). All VLCCs must maintain an under keel clearance of 3.5 meters and once they have entered the TSS must complete the transit. ${ }^{1}$
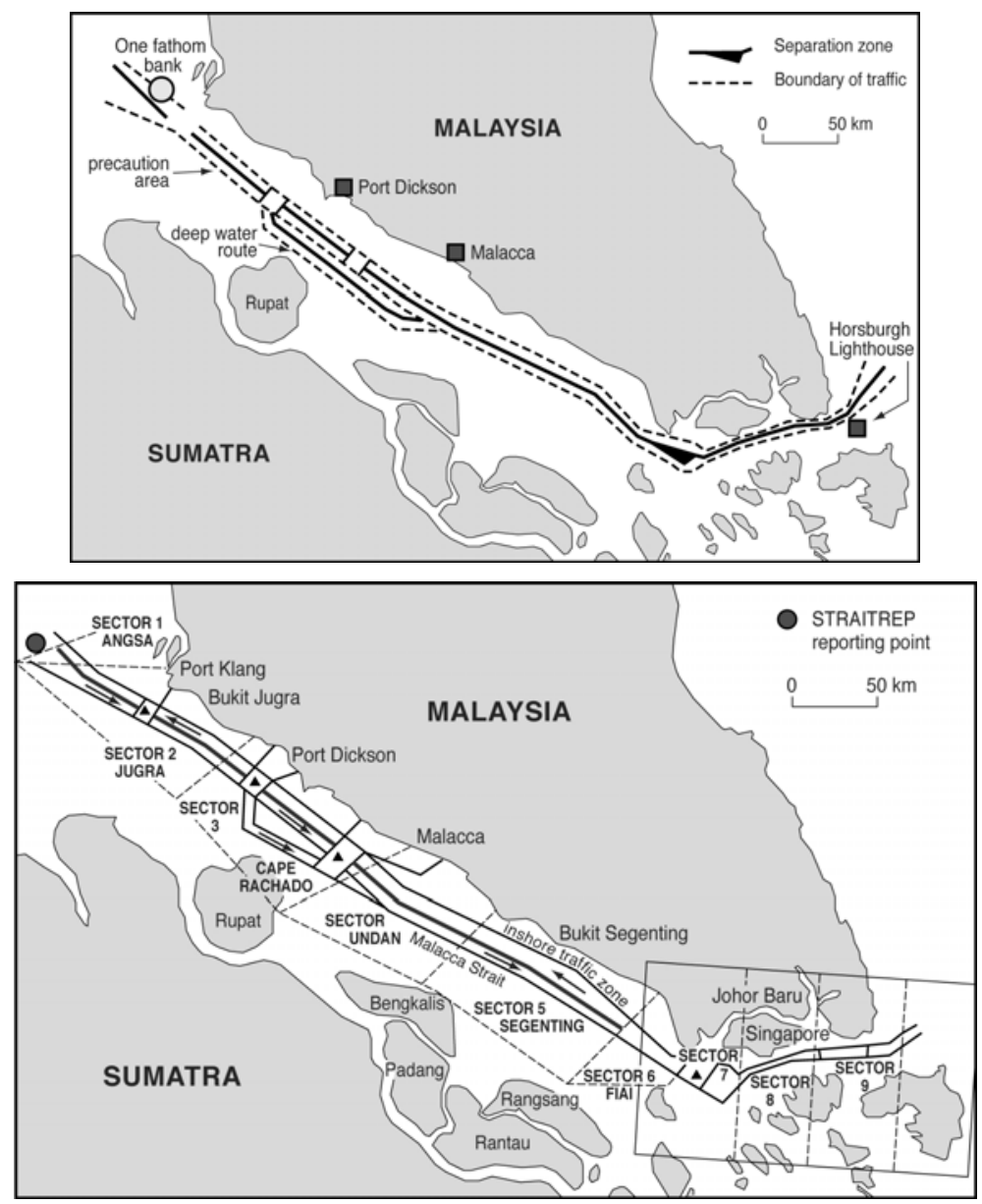

Source: Based on Oei (2001)

Fig 3. (a) The Traffic Separation Scheme in the Straits of Malacca and Singapore introduced in 1998; (b) Operation of the Area of Mandatory Ship Reporting System, in the Straits of Malacca and Singapore (STRAITREP)

${ }^{1}$ Most shipowners operate VLCCs with a draught shallower than 20.5 meters. 
If a Samsung class 321,000 dwt crude oil tanker sailing between the Persian Gulf port of Jubail in Saudi Arabia and the port of Ulsan in Korea is diverted through the deeper Lombok Strait it adds 2,532 nautical miles to the return voyage (Table 5). Assuming the carrier is sailing at 15 knots, the additional one-way journey time is 7 days and 48 minutes.

Table 5

Distance and time deviations from Malacca strait route for VLCC (321,000 dwt) on a return voyage between the ports of Jubail and Ulsan, 2006

\begin{tabular}{c|c|c|c|c}
\hline \multirow{2}{*}{ Route } & Distance & Time & \multicolumn{2}{|c}{ Deviation } \\
\cline { 2 - 5 } & (nautical miles) & (hours@ 15 knots) & (nautical miles) & (hours) \\
\hline \hline Malacca Strait & 12,426 & $828.4^{\mathrm{a}}$ & 0 & 0 \\
Lombok Strait & 14,958 & $997.2^{\mathrm{b}}$ & 2,532 & 168.8 \\
\hline
\end{tabular}

Notes: a) 34 days, 12 hours 24 minutes.

b) 41 days 48 minutes.

The cost of the deviation is based on the hire rate for the tanker (i.e. to cover crew and capital costs), the price of bunker fuel, and insurance charges (Table 6). Assuming (a) a daily hire rate of US\$45,000 based on 355 annual operating days, (b) the 2006 price of Singapore bunker fuel, and (c) a combined insurance fee covering both hull and machinery (H\&M) and protection and indemnity (P\&I) imposts, the total cost of the deviation is over US\$276,000 per vessel. Thus, the Lombok diversion adds over $20 \%$ to the original cost of US\$2.70 million for the round voyage through the Malacca and Singapore Straits.

Table 6

Costs of deviation for VLCC (321,000 dwt) on a return voyage between the ports of Jubail and Ulsan, 29 June $2006^{\mathrm{a}}$

\begin{tabular}{l|c|c|c}
\hline \multirow{2}{*}{ Item } & \multirow{3}{*}{ Assumption } & $\begin{array}{c}\text { Malacca and Singapore } \\
\text { Straits }\end{array}$ & Lombok Strait \\
\cline { 3 - 4 } & & (828.4 hours) & $(168.8$ hours $)$ \\
\hline \hline Hire rate & US\$45,000 & $1,552,500$ & 316,500 \\
Bunker & $96 M T S /$ day @US\$330 & $1,093,488$ & 222,816 \\
Insurance & US\$650,000/year $^{\mathrm{b}}$ & 63,200 & 12,878 \\
& & $2,709,188$ & 552,194 \\
\hline
\end{tabular}

Notes: a) Annual operating days 355.

b) Singapore price of MT Bunker CST380.

c) Hull and Machinery (H\&M) c.US\$250,000 and Protection \& Indemnity (P\&I) c.US\$400,000. In case of war, an insurance surcharge will be added to the insurance. All figures have been rounded. 


\subsection{Management Response}

Shipping company management can respond to this situation by either (a) increasing the ship's speed, or (b) bringing additional tankers onto the route. Information from our case studies of tanker operators suggests that the first option is impractical as to maintain the same navigating time as through the Straits of Malacca and Singapore would require an average speed over 18 knots, which is not only unbearable for most vessels but also would cause heavy consumption and costs. The second option of deploying additional tankers is based on the present market level for VLCCs operating in the Middle East Gulf-East Asian trade. Assuming, for illustrative purposes, 1,200 return voyages or fixtures are to be undertaken per year between Jubail and Ulsan and the average time for a single return voyage is 34.5 days, the total time for fulfilling all fixtures is 41,280 days (Table 7). By diverting through the Lombok Strait the average time for the voyage is increased by 7 days to 41.5 days. As a ship could fulfil 8.8 voyages per 355-day year, 998 fixtures could be fulfilled within the 41,280 days. The discrepancy is over 202 fixtures between the Lombok Strait and the 1,200 fixtures via the Malacca and Singapore Straits. Given that a ship can undertake 8.6 voyages per year, at least 24 additional tankers need to be deployed to compensate for the imbalance and maintain the whole fixtures. Extrapolating from the cost of a single return voyage from Table 6, the total cost of this deployment would be US\$673.1 million. ${ }^{2}$

\section{Table 7}

The deployment of additional ships to accommodate the diversion of tankers from the Malacca and Singapore straits to the Lombok strait, 2006

\begin{tabular}{l|c}
\hline MALACCA AND SINGAPORE STRAITS & 1,200 \\
\hline \hline Rough fixtures per year & 34.5 \\
Average time used for a single voyage (days) & $1,200 \times 34.5=41,400$ \\
Total time used to fulfil all fixtures per year (days) & $34.5+7.0=41.5$ \\
\hline DIVERTING TO LOMBOK STRAIT & $355 / 41.5=8.6$ \\
\hline Average time used for a single voyage (days) & $41,400 / 41.5=997.6$ \\
The number of voyages a ship could fulfil per year & $1,200-997.6=202.4$ \\
$\begin{array}{l}\text { Fixtures that could be done in 41,280 days } \\
\text { Discrepancy of fixtures between via Malacca and }\end{array}$ & \\
Singapore Straits and via Lombok Straits & $202.4 / 8.6=23.5$ \\
Additional ships to be deployed per year to compensate \\
the balance
\end{tabular}

\footnotetext{
${ }^{2}$ Akimoto (2001a,b, 2002) calculated that the Lombok diversion for tankers would add three days journey time for crude oil shipments from Middle East to Japan, require 15 extra tankers, and cost almost US\$88 million but provided no detailed figures on which he based his suppositions.
} 
The diversion of tankers from the Straits of Malacca and Singapore represents a substantial burden but the availability of the alternative route via the Lombok Strait lessens the impact of any impedance. Any blockade of the Straits of Malacca and Singapore, therefore, would have a less marked effect on spot prices for oil as would occur with the closure of the Strait of Hormuz leading to the Persian Gulf. As the supply/demand situation would certainly work in favour of operators and carriers, the market would rise and oil and fuel prices would increase.

One neglected aspect, as the tanker operators in our case studies highlight, is that if the Malacca and Singapore Straits were unavailable VLCCs would be deprived of their main bunkering port of Singapore. Most VLCCs in these circumstances would divert to the Port of Fujairah in the United Arab Emirates for replenishment. This may not only cause a rise in the bunkering price in Fujairah but also would represent a challenge to its bunkering capacity for to the high consumption of VLCCs. If there are insufficient bunkers to reach Fujairah the vessel will have to choose, regardless of price, the last discharge port for replenishment.

Even in the unlikely case of both the Straits of Malacca and Singapore and the Lombok Strait being interdicted, there is still an alternative (see Fig. 1). Given the problems of navigating the shallow Torres Strait, this would necessitate a round Australia diversion of 14 days and increase the journey cost by $81 \% .{ }^{3}$ Were this to occur, buffer oil stocks held by user states such as China, Japan and Korea would provide sufficient time to attract excess tanker capacity to the route and for shipping costs to be adjusted by shipping markets

\section{Container Ships}

The diversion of a container ship travelling between Suez and the port of Busan in Korea from the Malacca Straits would have the option of travelling through either the Sunda Strait or the Lombok Straits. As shown in Table 8, the Sunda Strait would add 1,086 nautical miles and the Lombok Strait 2,488 nautical miles. Assuming the ship was travelling at 25.5 knots, the Sunda Strait would add almost 43 hours and the Lombok Strait almost 98 hours to the journey. As the cost of the deviation will also vary with the size of the container ship, both a Samsung class 6,600 TEU and 8,300 TEU vessels are considered.

\footnotetext{
${ }^{3}$ Akimoto (2001a,b, 2002) also calculated a round Australia diversion for oil shipments from the Middle East to Japan, which would add 14 days journey time, 80 extra tankers and cost US\$1,200 million but again provided no basis for the calculation.
} 
Table 8

Distance and time deviations from Malacca strait route for a container ship on a round voyage between Suez and port of Busan, 2006

\begin{tabular}{l|c|c|c|c}
\hline \multirow{2}{*}{ Route } & Distance & Time & \multicolumn{2}{c}{ Deviation } \\
\cline { 2 - 5 } & nautical miles & hours@ 25.5 knots & nautical miles & hours \\
\hline \hline Malacca Strait & 14,860 & $582.8^{\mathrm{a}}$ & 0 & 0 \\
Sunda Strait & 15,946 & $625.4^{\mathrm{b}}$ & 1,086 & 42.6 \\
Lombok Strait & 17,348 & $680.4^{\mathrm{c}}$ & 2,488 & 97.6 \\
\hline
\end{tabular}

Notes: a) 24 days, 6 hours 48 minutes.

b) 26 days 1 hour 24 minutes.

c) 28 days 8 hours and 24 minutes.

The cost of the deviation for the Samsung 6,600 TEU class container ship is based on the hire rate for the container ship, the price of bunker fuel, which is the most significant item, and insurance charges (Table 9). Assuming (a) a daily hire rate of US\$40,000 based on 355 annual operating days, (b) the current price of Singapore bunker fuel and (c) a combined insurance fee of $\$ 400,000$ covering H\&M and P\&I charges, the total cost of the deviation over the US\$2.82 million for the Singapore and Malacca Straits route is almost US\$206,000 or 7.3\% for the Sunda Strait and almost US\$472,000 or $16.7 \%$ for the Lombok Strait.

Table 9

Costs of deviation for 6,500 TEU container ship sailing one-way between Suez and port of Busan, 29 June $2006^{\mathrm{a}}$

\begin{tabular}{l|c|c|c|c}
\hline \multicolumn{1}{c|}{ Item } & Assumption & $\begin{array}{c}\text { Malacca and } \\
\text { Singapore Straits } \\
(582.8 \text { hours })\end{array}$ & $\begin{array}{c}\text { Sunda Strait } \\
(42.6 \text { hours })\end{array}$ & $\begin{array}{c}\text { Lombok Strait } \\
(97.6 \text { hours })\end{array}$ \\
\hline \hline Hire rate & US\$40,000/day & 971,333 & 71,000 & 162,667 \\
Bunker & $227 M T S /$ day & $1,819,065$ & 132,966 & 304,634 \\
Insurance & USS $\$ 400,000 / 355$ days & 27,361 & 2,000 & 4,582 \\
Total & US $\$$ & $2,817,759$ & 205,966 & 471,882 \\
\hline
\end{tabular}

Notes: a) Annual operating days 355.

b) Singapore price of MT Bunker CST380.

c) Hull and Machinery (H\&M) c.US\$250,000 and Protection \& Indemnity (P\&I) c.US\$150,000. In case of war, an insurance surcharge will be added to the insurance. All figures are rounded.

The cost of diverting the larger Samsung 8,300 TEU class container ship from the Malacca Strait via either the Sunda Strait or Lombok Strait is correspondingly greater for the return voyage (Table 10). The increase stems from: (a) the higher hire rate of US\$50,000 per day, (b) the rise in 
consumption of bunker fuel from 227 MTS to 248 MTS per day, and (c) an increase in insurance costs stemming from a higher P\&I rate. The total cost of the deviation over the US\$3.2 million for the Malacca and Singapore Straits through the Sunda Strait is almost US\$237,000 and through the Lombok Strait is almost US\$541,000, 7.3\% and 16.7\% respectively.

Table 10

Costs of deviation for 8,300 TEU container ship sailing one-way between Suez and the port of Busan, 29 June 2006 ${ }^{\text {a }}$

\begin{tabular}{l|c|c|c|c}
\hline \multicolumn{1}{c|}{ Item } & Assumption & $\begin{array}{c}\text { Malacca and } \\
\text { Singapore Straits } \\
(582.8 \text { hours })\end{array}$ & $\begin{array}{c}\text { Sunda Strait } \\
(42.6 \text { hours })\end{array}$ & $\begin{array}{c}\text { Lombok Strait } \\
(97.6 \text { hours })\end{array}$ \\
\hline \hline Hire rate & US\$50,000/day & $1,214,167$ & 88,750 & 203,333 \\
Bunker & $\begin{array}{c}\text { 248MTS/day } \\
\text { @US } \$ 330^{\mathrm{b}}\end{array}$ & $1,987,075$ & 145,675 & 332,843 \\
Insurance & US\$450,000/355 days ${ }^{\mathrm{c}}$ & 30,778 & 2,256 & 5,146 \\
\hline Total & US $\$$ & $3,232,020$ & 236,681 & 541,322 \\
\hline
\end{tabular}

Notes: a) Annual operating days 355.

b) Singapore price of MT Bunker CST380.

c) Hull and Machinery (H\&M) c.US\$250,000 and Protection \& Indemnity (P\&I) c.US\$200,000. In case of war, an insurance surcharge will be added to the insurance. All figures are rounded.

Again, shipping companies can respond to this situation by either by: (a) increasing the ship's speed, or (b) bringing additional vessels onto the route. As shipping company respondents do not see increasing speed as a practical option, the more realistic alternative is to deploy additional containers ships. Presuming, for illustrative purposes, 1, 200 fixtures are to be undertaken per year between Suez and Busan and the average time for a single return voyage is 24.3 days, the total time for fulfilling all fixtures is 29,160 days (Table 11). By diverting through the Sunda Strait the average time for the voyage is increased by 1.8 days to 26.1 days. As a result the container ship can undertake 13.6 voyages per 355-day year — one less than through the Malacca and Singapore Straits. Only 1,117 fixtures can be fulfilled within the 29,160 days rather than the 1,200 fixtures that are possible through the Malacca and Singapore Straits. At least an additional seven container ships need to be deployed to compensate. An identical exercise can be undertaken for the Lombok diversion. As the voyage time is increased by 4.1 days to 28.4 days the ship can fulfil only 12.5 voyages during the 355-day year. Consequently, the number of fixtures within 29,160 days is reduced to 1,026 — a shortfall of 174 fixtures compared with the Malacca and Singapore Straits. The deployment of 14 additional container ships is required to maintain 1,200 fixtures. 
Table 11

The deployment of additional ships to accommodate diversions of container ships from the Malacca and Singapore straits to the Sunda strait and the Lombok strait, 2006

\begin{tabular}{l|c}
\hline MALACCA AND SINGAPORE STRAITS & 1200 \\
\hline \hline Rough fixtures per year & 24.3 \\
Average time used for a single voyage (days) & $1,200 \times 24.3=29,160$ \\
Total time used to fulfil all fixtures per year (days) & \\
\hline DIVERTING TO SUNDA STRAIT & $24.3+1.8=26.1$ \\
\hline Average time used for a single voyage (days) & $355 / 26.1=13.6$ \\
The number of voyages a ship could fulfil per year & $29,160 / 26.1$ \\
Fixtures that could be done in 29,160 days & $1,200-1,117.2=82.8$ \\
Discrepancy of fixtures between via Malacca and Singapore & \\
Straits and via Lombok Straits & $82.8 / 13.6=6.1$ \\
Additional ships to be deployed per year to compensate the & \\
balance & $24.3+4.1=28.4$ \\
\hline DIVERTING TO LOMBOK STRAIT & $355 / 28.4=12.5$ \\
\hline Average time used for a single voyage (days) & $29,160 / 28.4=1,026$ \\
The number of voyages a ship could fulfil per year & $1,200-1,026=174$ \\
Fixtures that could be done in 29,160 days & \\
Discrepancy of fixtures between via Malacca and Singapore & $174 / 12.5=13.9$ \\
Straits and via Lombok Straits & \\
Additional ships to be deployed per year to compensate the & \\
balance & \\
\hline
\end{tabular}

As the costs for additional container ships vary with the size of vessel, the cost of return voyages of Samsung class 6,600 and 8,300 TEU container ships are extrapolated from Tables 9 and 10 to calculate the total. Seven additional 6,600 TEU ships to transit the Sunda Strait would cost US\$21.2 million compared with US\$23 million for an equivalent number of 8,300 TEU vessels; the average cost reduces from US\$458 per TEU from the smaller ship to US\$396 per TEU for the larger. Fourteen additional 6,600 TEU vessels to transit the Lombok Strait would cost US\$48.6 million and US\$52.8 million for an equal number of 8,300 TEU vessels; the average cost per TEU decreases with the shift in ship size from $\$ 525$ per TEU to US\$455 per TEU, underlining the economies of scale offered by larger vessels.

\subsection{Disrupting Mega-Ports}

Our calculations reflect the costs of the diversion but do not cover the economic losses from any disruption to the rigid global hub and spoke systems of which container shipping is an integral part. Activities of global container shipping alliances are concentrated on mega-ports and their feeder systems. The mega-ports offer depths alongside, length of berths, and gantry cranes that are capable of handling 6,600 TEU and 8,300 TEU container ships. Any disruption 
to the global hub-and-spoke system would affect worldwide production lines based on 'just-intime' operations, particularly as logistics companies will take much longer to institute counter measures. If there is impedance to container terminal operations it will have a greater impact because a total logistics system is involved rather than one or more ships, as is the case with tankers.

These impacts are difficult to gauge. One rule-of thumb espoused by Kazumine Akimoto (2001b) is that if tanker traffic in the Malacca and Singapore Straits were blocked 3\% of the cargo's value would be lost. Given the landed price of crude oil in Korea is US\$459.20 per dwt (2006); this loss would amount to US\$4.2 million for a Samsung class 321,000 dwt tanker. ${ }^{4}$

However, in the case of the closure of a mega-port like Singapore, Akimoto's rule-of-thumb is that some $20 \%$ of the cargo's value would be lost. Given that the Korean Container Port Authority and field experts at the Port of Busan advise that the empty container rate per ship is $20 \%$, the average value of full and empty containers imported into the country for 2005, according to Korean Customs export-import commodity price data, is US\$34,216, which would represent US\$45 million for a 6,600 TEU vessel and over US\$57 million for a 8,300 TEU vessel.

Rule-of-thumb calculations are indicative but inadequate, particularly as opinions differ markedly on the possibilities of redirecting shipping from a hub port to other ports. Contrary to the findings of the United States Congressional Budget Office's Report on the economic costs of disruptions in container shipments with reference to Hong Kong, Akimoto (2001b), for instance, contends that the paralysis of a hub port like Singapore would know no bounds and, given that almost one vessel arrives every two minutes it would be impossible to redirect all ships to other ports. Given this divergence of opinion, we draw on insights from company case studies as to what would happen if Singapore were closed in the short or long term. Options will include using alternative hub ports and feeder strings, larger container ships and alternative transport modes.

According to information derived from these case studies, the outcome of any closure of Singapore will depend on the availability of transit through the Malacca and Singapore Straits. Given that Singapore is a key hub port for the transfer of cargo between Southeast Asia to North America, Australasia and Asia, with a valuable and steady weekly volume, a single port may not be able to accommodate the throughput from the port's closure. Several ports may have to undertake the task. Hong Kong, Colombo, Shenzhen, Kaohsiung and, possibly, Laem Chabang were seen as the most likely replacements for consolidating Singapore's traffic, although feeder costs will increase substantially. Foregoing transhipment altogether and the deployment of smaller ships, as mentioned in the CBO (2006) study, are not seen as feasible propositions. A switch to smaller vessels is deemed unwise, as the prevailing trend is to deploy 5,000-6,000 TEU vessels from Southeast Asia to Europe and North America because they offer operator's economies of scale.

If the Straits were still open, shipments could also be diverted to regional ports that have been aggressively competing with Singapore for additional business. In particular, Port Kelang and the

\footnotetext{
${ }^{4} \mathrm{~A}$ Korean chartering company (pers. comm. 2006) advises that the FOB value at a Korean port is US\$63.50 per barrel plus a freight rate of US\$2.10 per barrel handling fee which totals US\$65.60. As there are 7 barrels in $1 \mathrm{dwt}$ US\$65.6 $\times 7$ = US\$459.20 per dwt.
} 
Port of Tanjong Pelepas are expected to take a good share of the traffic from any closure of Singapore. Even though the two ports could consolidate shipments from Singapore, the accommodation of $25 \%$ or 5 million TEU of throughput is seen as a potential burden to them and likely to cause operational problems and some troubles in daily practise. Indeed, Hong Kong is the only port nominated as being able to accommodate more than $25 \%$ of Singapore's cargo.

Given that ocean carriers/operators have already decided that to hub on Singapore is the most practical and cost-efficient solution, any disruption would lead to a rise in the costs of shipments. This rise would be most marked in the Asia to Europe trade, as the impact of the voyage deviation on the cost of shipments would be raised considerably; the cost in the Asia to North America trade may have to increase slightly. Although smaller ports have lower handling and transshipment charges, the operators did not expect any large diversion to them given the difficulties in switching services and downsizing ships, and the current shortage of feeder space. If ocean carriers called at too many smaller ports, costs would increase and schedules would be seriously disrupted and delayed and additional tonnage and ships required. Inevitably, costs would increase. Any additional costs to shipping operators would be passed on to shippers with the prospect of higher valued goods generated through Southeast Asia's advancing industrialization and globalization being switched to air transport. These responses suggest that while flow analysis may be suitable for studying tankers, we need to redirect our future efforts to investigating the role of container shipping within supply chains.

\section{Conclusions}

This study has sought to identify the costs if tankers or container ships were impeded by the interdiction of the Malacca and Singapore Straits en route to and from Korean ports. Ideally, a comparison of our work with Akimoto's (2001a,b, 2002) study based on Japanese experience should have been undertaken but, as noted, this was precluded by the absence of detailed information on the basis of his calculations. However, this comparison is more pressing, as Korea is not only the world's eleventh largest economy but also its fourth largest importer of crude oil. ${ }^{5}$ While our analysis of crude oil tankers can be extended to future examinations of LNG and LPG tankers and dry bulk vessels, we need to redirect our work on container shipping to explore possible alternative ports if key hubs are closed for either short or long periods.

In pursuing this task we are aware that shipowners are considering container ships larger than the Samsung class 8,300 TEU used in this study (Table 12). Reportedly, Samsung Heavy Industries Co. Ltd. is discussing possible orders with China Shipping Container Line for its 9,000 TEU prototype. Although doubts have been raised by Martin Stopford (2002) about the small economies offered by larger vessels, Philip Damas (2006) has reported that a Samsung

\footnotetext{
${ }^{5}$ During the first six months of 2006 The Australian (14 August 2006) reported that the cost of crude oil shipment from the Middle East to South Korea increased by $49 \%$ to almost US\$31 billion - US\$5 billion more than the country's imports from Japan.
} 
representative has argued that the unit cost for a 9,000 TEU is US\$171 compared with US\$208 for a 4,500 TEU vessel.

Table 12

Comparisons of the specifications of Samsung class 6,600 TEU and 8,300 TEU vessels with Malacca max

\begin{tabular}{l|c|c|c}
\hline & Samsung class & Samsung class & Malacca max \\
\cline { 2 - 4 } & 6,600 TEU & 8,300 TEU & 18,000 TEU \\
\hline \hline Length over all (meters) & 299.8 & 334.0 & 400.0 \\
Breadth (meters) & 40.0 & 42.8 & 60.0 \\
Depth to main deck (meters) & 24.6 & 24.6 & 35.0 \\
Draught, design (meters) & 13.0 & 13.0 & 21.0 \\
Draught, scantling (meters) & 14.0 & 14.5 & 23.1 \\
Service speed(knots) & 25.9 & 26.1 & 25.0 \\
Container capacity & 6,630 & 8,308 & 18,154 \\
\hline
\end{tabular}

Source: SHI (2004) and Baird (2004)

Research is also being undertaken by Niko Wijnolst and associates at Delft University on the revolutionary Malacca-max type container vessels of 18,000 TEU that would have the maximum size and draft to transit the Straits of Malacca and Singapore (Wijnolst, Scholtens and Waals, 1999). No shipping line is reported to be considering a vessel of this size but 12,000 TEU ship size is expected before 2010 requiring depth alongside of 16 metres, berth lengths of 450 meters and gantry cranes with an outreach of over 60 meters (Rizvi, 2003). Also Samsung Heavy Industries Co. Ltd. is believed to be developing a 14,000 TEU prototype. Therefore, there is a pressing need to develop an analytical framework that ascribes economic value not only to the container ships but also to the terminals and inland transport systems to gauge the full impact of any impedance to container shipping in the Straits of Malacca and Singapore. Inevitably, this wider focus will lead us into a deeper analysis of security in global supply chains.

\section{Acknowledgments}

The assistance of shipping companies providing case study material is much appreciated, although they prefer to remain anonymous. Thanks are due to Matthew Flynn of Flynn Associates for using his good offices on our behalf; to Tom Grigalunas for providing additional reference material; to Sue Rimmer for editorial advice; and to Kay Dancey, Cartographic Section, Research School of Pacific and Asian Studies, The Australian National University, Canberra for drawing the figures. 


\section{References}

The Australian. 2006. Special report on South Korea, Monday August 14 2006: 17.

Abd Rahim bin Hassin. 2005. The Management of the Straits of Malacca: Power sharing as the basis for cooperation. Paper presented at the LIMA International Conference 2005, Awana Porto Malai, Langkawi, Malaysia 4-5 December.

www.mima.gov.my/mima/htmls/conferences/LIMA05/rahim-present.pdf

Akimoto, Kazumine. 2001a. Re-routing options and consequences. Paper presented at the $13^{\text {th }}$ International Conference on Sea Lines of Communication entitled 'The Strategic Importance of Seaborne Trade and Shipping: A Common Interest of Asia Pacific'. The Chifley Hotel, Canberra, 3-4 April 2001.

Akimoto, Kazumine. 2001b. The Current state of maritime security: Structural weaknesses and threats in the sea lanes. Paper presented at the conference on Maritime Security in Southeast Asia and Southwest Asia, Institute for Policy Studies, Tokyo, 3 December. community.middlebury.edu/ scs/docs/Akimoto_paperSealanes\%20and\%20security.pdf

Akimoto, Kazumine. 2002. Kaijo unso to kiki kanri: shi-re-no kozo teki na zejakusei to kyoi (Marine transport and crisis management: Structural fragility and threat to sealanes), Kaiji Sangyo Kenkyujo Ho (Japan Maritime Research Bulletin), No. 428: 18-24.

Akiyama, Masahiro. 2004. Defending sea lanes vital to a nation's interests. Asahi Shimbun, 1 September, 2004.

Baird, Alf. 2004. Container transhipment and demand for container terminal capacity in Scotland. Edinburgh: Scottish Executive. www.scotland.gov.uk

Bergin, A. and S. Bateman. 2005. Future unknown: The terrorist threat to australian maritime security. Canberra: The Australian Strategic Policy Institute.

Brown, Christopher. 2005. Submission by the International Group of P\&I Clubs, IMO Jakarta Meeting on the Straits of Malacca and Singapore: Enhancing Safety, Security and Environmental Protection, 7-8 September, 2005.

http://www.ukpandi.com/ukpandi/Infopool.nsf/HTML/ClubEvents20050907

CBO. 2006. The economic costs of disruptions in container shipments. Washington, DC: Congressional Budget Office, US Congress. http://www.cbo.gov

Chen, J. 2006. Reversing the Joint War Committee's (JWC) war risk decision in the Malacca Straits: An interim review. Singapore: Singapore Institute of International Affairs. http://www.siiaonline.org/reversing_the_joint_war

Coulter, Daniel Y. 2002. Globalization of maritime commerce: The rise of hub ports. Sam J. Tangredi, Globalization and maritime power, 133-142. Washington, DC: Institute for National Strategic Studies, National Defense University.

http://www.ndu.edu/inss/books/Books_2002/Globalization_and_Maritime_Power_De c_02/01_toc.htm

Damas, Philip. 2006. How much bigger will boxships get? American Shipper www.americanshipper.com/paid/MAY01/how_much_bigger.asp 
Desker, B. 2005. Protecting the Malacca Strait. IDSS Commentaries. Singapore: Institute of Defence and Strategic Studies.

community.middlebury.edu/ scs/ docs/desker-malacca\%20strait\%20security.pdf

Djalal, Hasjim. 2004. The Malacca-Singapore Straits issue. Paper presented at the Conference on 'The Straits of Malacca: Building a Comprehensive Security Environment, October 11-13, 2004, Prince Hotel \& Residence, Kuala Lumpur.

www.mima.gov.my/mima/htmls/conferences/som04/papers/hasjim-djalal.pdf

IMB. 2006a. Piracy and armed robbery against ships: Annual report for the period 1 January-31 December 2005. London: International Chamber of Commerce (ICC) International Maritime Bureau.

IMB. 2006b. Piracy and armed robbery against ships: Report for the period 1 January-31 March 2006. London: International Chamber of Commerce (ICC) International Maritime Bureau.

IMO. 2006a. Reports on acts of piracy and armed robbery against ship. Annual Report 2005. Ref. T2-MSS/2.11.4.1, MSC.4/Circ. 81. London: International Maritime Organization.

IMO. 2006b. Reports on acts of piracy and armed robbery against ships. Ref. T2-MSS/2.11.4.1, MSC.4/Circ.85 5 May 2006. London: International Maritime Organization.

Koh, Keng Lian. 1982. Straits in international navigation: Contemporary issues. London: Oceana Publications Inc.

Morisugi, Hisayoshi, James Barney Marsh, and Miyatake Nobuhuru. 1992. James Barney Marsh. ed. Economic value of the Malacca Strait. Resources and environment in Asia's marine sector: 307-334. New York.

Oei, P. 2001. Implications of vessel monitoring systems, electronic highways etc: Positives and negatives. Paper presented at the $13^{\text {th }}$ International Conference on Sea Lines of Communication entitled 'The Strategic Importance of Seaborne Trade and Shipping: A Common Interest of Asia Pacific', The Chifley Hotel Canberra, 3-4 April.

Raymond, Catherine Z. 2005a. Piracy in Southeast Asia: New trends, issues and responses. Working Paper No. 89. Singapore: Institute of Defence and Strategic Studies. www.ntu.edu.sg/IDSS/publications/WorkingPapers/WP89.pdf

Raymond, Catherine Z. 2005b. The Malacca Straits and the threat of maritime terrorism, PINR [Power and Interest News Report], 1 August 2005.

http://www.pinr.com/report.php?ac=view_printable\&report_id=352\&language_id=1

Raymond, Catherine Z. 2006. Maritime terrorism in Southeast Asia: Potential scenario. Global Terrorism Analysis, 4(7). The Jamestown Foundation

http://www.jamestown.org/terrorism/news/article.php?articleid=2369950

Rimmer, P.J. 2003. Les détroits de Malacca et de Singapour: États côtiers et États utilisateurs. Études Internationales, 34(2): 227-252.

Rizvi, Zia. 2003. The Containership. How big? — The Port Authority’s dilemma. www.npa.co.za/.../Tuesday\%2027\%20May\%2003/Zia\%20Rizvi\%20-\%20DurbanPP-Presentation-Revised.ppt

SHI. 2006. Samsung Heavy Industries Co. Ltd. Geoje Shipyard. Homepage: shi: samsung.co.kr Stopford, Martin. 2002. Is the drive for ever larger containerships irresistible? Paper presented at 
the Containerisation International Shipping Forecasting Conference, 2002. www.eclac.cl/transporte/perfil/Martin_Stopford.pdf

Wagner, Daniel. 2005. Expert commentary: Achieving security in the global supply chain. Trade Finance Magazine (Asian Trade Finance Supplement), August. http://www.irmi.com/expert/Articles/2005/Wagner10.apsx

Watkins, E. 2004. Facing the terrorist threat in the Malacca Straits. Terrorism Monitor, 2(9) May 6, 2. www.jamestown.org/publications_details.php?volume_id=400\&issue_id=2945\&artic le_id=236671 - $31 \mathrm{k}$

Wijnolst, Niko, Marco Scholtens, and Frans Waals. 1999. Malacca-Max: The ultimate container carrier. Delft: Delft University Press. 